\title{
man \\ A Developed Plasmatron Design to Enhance Production of Hydrogen in Synthesis Gas Produced by a Fuel Reformer System
}

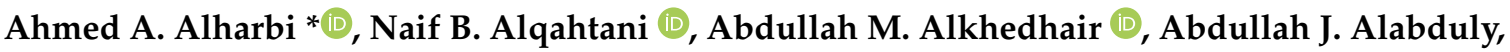 \\ Ahmad A. Almaleki, Mustafa H. Almadih, Miqad S. Albishi and Abdullah A. Almayeef
}

\section{check for} updates

Citation: Alharbi, A.A.; Alqahtani, N.B.; Alkhedhair, A.M.; Alabduly, A.J.; Almaleki, A.A.; Almadih, M.H.; Albishi, M.S.; Almayeef, A.A. A Developed Plasmatron Design to Enhance Production of Hydrogen in Synthesis Gas Produced by a Fuel Reformer System. Energies 2022, 15, 1071. https://doi.org/10.3390/ en15031071

Academic Editor: Marek Sciazko

Received: 25 November 2021

Accepted: 27 January 2022

Published: 31 January 2022

Publisher's Note: MDPI stays neutral with regard to jurisdictional claims in published maps and institutional affiliations.

Copyright: (C) 2022 by the authors. Licensee MDPI, Basel, Switzerland. This article is an open access article distributed under the terms and conditions of the Creative Commons Attribution (CC BY) license (https:// creativecommons.org/licenses/by/ $4.0 /)$.
King Abdulaziz City for Science and Technology (KACST), P.O. Box 6086, Riyadh 11442, Saudi Arabia; nqahtani@kacst.edu.sa (N.B.A.); akhoder@kacst.edu.sa (A.M.A.); alabduly@kacst.edu.sa (A.J.A.); aalmaleki@kacst.edu.sa (A.A.A.); malmadih@kacst.edu.sa (M.H.A.); malbishi@kacst.edu.sa (M.S.A.); amayeef@kacst.edu.sa (A.A.A.)

* Correspondence: ahalharbi@kacst.edu.sa

\begin{abstract}
Feeding IC engines with hydrogen-rich syngas as an admixture to hydrocarbon fuels can decrease pollutant emissions, particularly NOx. It offers a potential technique for low-environmental impact hydrocarbon fuel use in automotive applications. However, hydrogen-rich reformate gas (syngas) production via fuel reforming still needs more research and optimization. In this paper, we describe the effect of a plasma torch assembly design on syngas yield and composition during plasmaassisted reforming of gasoline. Additionally, erosion resistance of the cathode-emitting material under the conditions of gasoline reforming was studied, using hafnium metal and lanthanated tungsten alloy. The gasoline reforming was performed with a noncatalytic, nonthermal, low-current plasma system in the conditions of partial oxidation in an air and steam mixture. To find the most efficient plasma torch assembly configuration in terms of hydrogen production yield, four types of anode design were tested, i.e., two types of the swirl ring, and two cathode materials while varying the inlet air and fuel flow rates. The experimental results showed that hydrogen was the highest proportion of the produced syngas. The smooth funnel shape anode design in Ring 1 at air/fuel flow rates of 24/4, $27 / 4.5$, and $30 / 5 \mathrm{~g} / \mathrm{min}$, respectively, was more effective than the edged funnel shape. Lanthanated tungsten alloy displayed higher erosion resistance than hafnium metal.
\end{abstract}

Keywords: plasma; fuel reforming; syngas production; plasma torch

\section{Introduction}

Recently, there has been great concern about air pollution caused by increased levels of exhaust emissions due to their adverse impacts on the environment and human health. Internal combustion engines produce large amounts of harmful emissions, in particular; nitrogen oxide (NOx) emissions. NOx emissions from IC engines are estimated to be about half of the total amount of NOx emitted into the environment globally. Reforming of hydrocarbon fuels is a candidate technique that affords the opportunities to decrease the pollutant emissions of internal combustion (IC) engines. This technique involves the reactions of motor fuels with oxygen or water, or both combined as oxidizing agents. The main product is the mixture of hydrogen $\mathrm{H}_{2}$, and carbon monoxide $\mathrm{CO}$, with a variable component ratio known as syngas or reformate. In this regards, supplemental feeding of IC engines with hydrogen-rich syngas using on-board fuel reforming systems can significantly reduce NOx and soot emissions, especially under lean combustion mode [1-6]. Another approach involves the use of syngas as a feedstock in fuel cells for automotive applications, for example, in auxiliary power units (APUs) of heavy-duty vehicles or maritime transport [7-10]. 
The fuel reforming process inherently includes a nonstoichiometric reaction of fuel components with oxygen, known as partial oxidation (POX). The partial oxidation of hydrocarbons is usually described by the idealized equation as follows:

$$
\mathrm{C}_{\mathrm{n}} \mathrm{H}_{\mathrm{m}}+(\mathrm{n} / 2) \mathrm{O}_{2}=(\mathrm{m} / 2) \mathrm{H}_{2}+\mathrm{nCO}\left(\Delta \mathrm{H}_{\mathrm{r}}<0\right)
$$

In real systems, the partial oxidation of fossil fuels also produces some amounts of carbon dioxide and water, as a result of competing reactions of the full oxidation of hydrocarbons:

$$
\mathrm{C}_{\mathrm{n}} \mathrm{H}_{\mathrm{m}}+\mathrm{aO}_{2}=\mathrm{bCO}+\mathrm{cH}_{2}+\mathrm{dCO}_{2}+\mathrm{eH}_{2} \mathrm{O}\left(\Delta \mathrm{H}_{\mathrm{r}}<0\right)
$$

Equation (1) is favored thermodynamically at temperatures above $1000 \mathrm{~K}\left(726^{\circ} \mathrm{C}\right)$. However, temperatures of $1300 \mathrm{~K}\left(1026^{\circ} \mathrm{C}\right)$ and higher are required in noncatalytic systems to obtain high levels and rates of fuel conversion. Partial oxidation is an exothermic process; therefore, on the one hand, POX reformers advantageously have no need for external heating. By some estimates, approximately $15 \%$ of the calorific value is discharged as heat during the partial oxidation of liquid fuels (e.g., diesel and gasoline). On the other hand, the high temperatures which are required for partial oxidation can cause the pyrolysis of fuel components and derivatives under deficit of an oxidizer [11].

Hydrocarbon pyrolysis can result in carbon deposits inside reactors, causing POX catalyst degradation or flow clogging in noncatalytic reactors. Water admixing to the reaction medium can prevent the formation of pyrolytic carbon. Water is an additional oxidizer for carbon as well as a reagent in the steam reforming (SR) of hydrocarbons, according to the following equations:

$$
\begin{gathered}
\mathrm{C}+\mathrm{H}_{2} \mathrm{O}=\mathrm{H}_{2}+\mathrm{CO}\left(\Delta \mathrm{H}_{\mathrm{r}}>0\right) \\
\mathrm{C}_{\mathrm{n}} \mathrm{H}_{\mathrm{m}}+\mathrm{aH}_{2} \mathrm{O}=\mathrm{bCO}+\mathrm{cH}_{2}+\mathrm{dCO}_{2}+\mathrm{eH}_{2} \mathrm{O}\left(\Delta \mathrm{H}_{\mathrm{r}}>0\right)
\end{gathered}
$$

A combination of Equations (2) and (4) describes the practical process of autothermal reforming (ATR) of hydrocarbon fuels.

$$
\mathrm{C}_{\mathrm{n}} \mathrm{H}_{\mathrm{m}}+\mathrm{aO}_{2}+\mathrm{bH}_{2} \mathrm{O}=\mathrm{cCO}+\mathrm{dH}_{2}+\mathrm{eCO}_{2}+\mathrm{fH}_{2} \mathrm{O}\left(\Delta \mathrm{H}_{\mathrm{r}} \approx 0\right)
$$

This process is thermodynamically neutral, because heat released in the exothermic partial oxidation is consumed in the endothermic SR process.

Noncatalytic fuel reformers have several advantages, which includes eliminating some conventional problems related to catalysts, such as poisoning by fuel impurities, a narrow range of operating temperatures, slow response times, and sensitiveness to fuel compositions. However, a temperature of at least $1300 \mathrm{~K}$ is required at atmospheric pressure for rapid initiation and efficient operation of noncatalytic partial oxidation, and therefore, the whole fuel reforming process. In on-board systems, these temperatures can be achieved either by burning some part of a motor fuel or by transferring heat from an external source. Plasma systems can be used as effective external heat sources in fuel reforming applications. A plasmatron design enables rapid ohmic heating of gaseous fuel-air-steam mixtures to high temperatures due to high energy densities generated by plasma. The high temperature, then, causes ionization of the gas mixture components. These plasma phenomena increase reaction rates, and therefore, result in an increased speed of response, wider variety of processable fuels, and reduced reactor dimensions for efficient on-board reforming. In simplified form, there are two main sets of charged species in the ionized plasma medium: heavy species (radicals, atoms, molecules, and ions) and electrons ("electron gas"). In most types of plasma systems, the main macroscopic physical parameter, i.e., temperature, is equal for all these species; therefore, the thermodynamic equilibrium is kept in the system. This kind of plasma is referred to as thermal plasma. These temperature conditions can easily be accomplished by supplying a high energy flow 
to the plasma system. This energy flow can be created, for example, in an electric arc by applying a very high electrical current between electrodes. The thermal plasma fractures all the molecules in the gaseous medium, especially the less stable ones such as hydrocarbons. Then, the ionized molecular fragments can recombine to form a new set of the simplest molecules. Thus, fuel reforming in the thermal plasma conditions requires high-energy consumption in the range of tens or more kilowatts, and high electrical currents of tens and hundreds of amperes to keep the plasma active. These disadvantageous requirements substantially decrease the energy performance of a candidate on-board plasma system. In addition, high operational currents and temperatures cause erosion of electrodes limiting the system operational lifetime [12-17].

A more promising approach in the on-board fuel reforming process is using nonthermal plasma systems. This kind of plasma is not in full thermodynamic equilibrium because the temperature of the electron cloud is much higher than the temperature of heavy species. Ionization of heavy species is not full, and enthalpy increases are not substantial as compared with the thermal plasma; however, fuel-reforming reactions are eminently catalyzed by nonthermal plasma. In this case, the plasma medium is the source of active species formed at relatively low reagent temperatures. Nonthermal plasma reformers can be more efficient because they are characterized by lower energy consumption. It should be noted that the energy demands are particularly critical for on-board applications. Many various embodiments of nonthermal plasma-assisted reformers of hydrocarbon liquid fuels have been proposed. Among them are reformers boosted, for example, by microwave plasma [18-20], low current-high voltage arc discharges [15,16], corona discharges [21], spark discharge [22] plasmas, gliding arc [17-19,23] etc.

The main energy output in arc discharge plasmas occurs in the core region of the arc, as shown in Figure 1. Thereby, two parallel opportunities for enhancing the reaction occur in this region of the plasma [24-28]. The first is the generation of chemically active ionized species due to collisions of gas molecules and electrons, followed by reactions of these species. The second is the "usual" thermal activation of gas reactions by heat transfer from electric discharges. The temperature of the nonthermal discharge arc has been estimated as 2000-6000 K, depending on the process conditions [28,29]. The length of the arc can influence the fuel reforming process, affecting both the amount of heat transferred to the reactants and the generation of ionized active species.

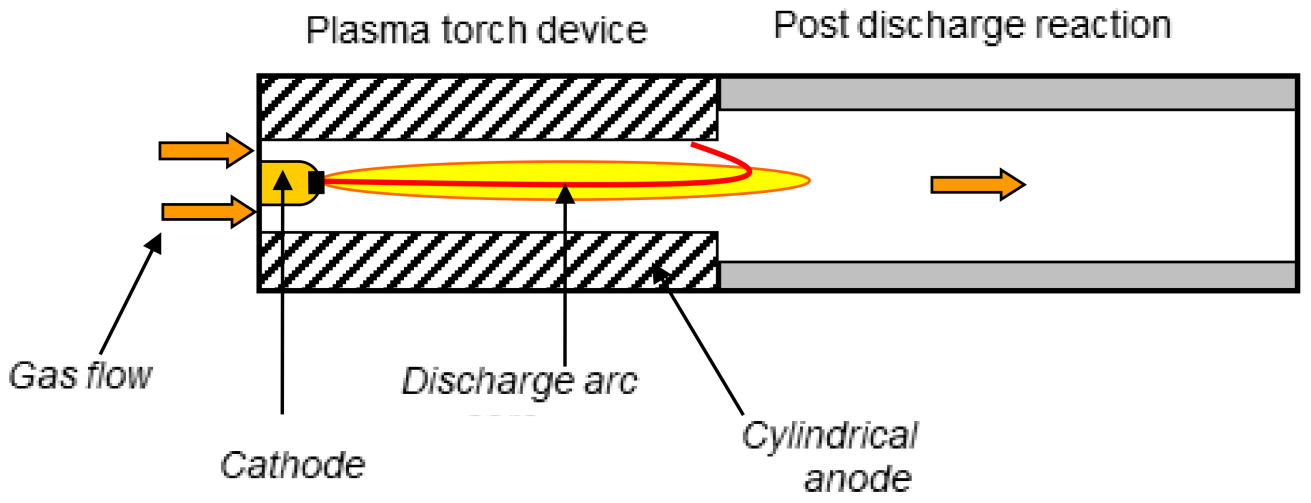

Figure 1. Scheme of a low-current plasma reformer.

Arc elongation increases the density of the discharge electrons, which accelerates the ionization of gas species [30], as well as boosts heat transfer to the reagents. This combined effect can improve the overall reforming process, yielding more syngas from the same process inputs [31]. Modeling and experiments have shown that arcs generated in laminar gas flow are usually longer than arcs formed in transient or turbulent conditions [16,32,33]. The swirling (vortex) flow with laminar character through the discharge area can additionally extend and stabilize the arc length. Moreover, the flow pattern depends on the design and configuration features of the plasma reactor [34,35]. Therefore, the arc length is set by 
intrinsic characteristics of the plasma system, i.e., the geometry, the fluid dynamics, electric parameters, etc.

This study is part of a research program dedicated to developing plasma-enhanced fuel reforming, with a view to decrease pollutant emissions from IC engines. Previous studies [36-40] have shown the effect of admixing hydrogen-rich syngas with fuel on decreasing the NOx levels of IC engines. In the present work, the effect of varying the geometry of the anode, the cathode material, and inlet flow characteristics of the plasma torch on the performance of the fuel reforming process were investigated. The optimal configuration of the plasma torch with highest hydrogen yield was identified and employed for further operation.

The current study showed a slight increase in the hydrogen production (about 24\%) from syngas as comparing with $23 \%$ of hydrogen using a propane-butane mixture conducted by Feraih et al. where a high voltage atmospheric discharge plasma system was developed to convert a propane-butane mixture and air into syngas. Approximately $23 \%$ hydrogen was observed in the reaction product, which corresponded to $77 \%$ conversion using a numerical model of the process. A good correlation was observed between the experimental and numerical data, demonstrating the validity of the proposed assumptions regarding the thermal properties of the plasma under the studied conditions [41]. An on-board plasma fuel reformer was employed for the production of hydrogen-rich syngas via the partial oxidation of gasoline [39]. The time-averaged steady-state chemical composition of the syngas was $13 \% \mathrm{H}_{2}, 14 \% \mathrm{CO}$, and $7 \% \mathrm{CO}_{2}$. While in the current study, after designing the plasmatron system, the syngas component results are $24 \% \mathrm{H}_{2}, 19 \% \mathrm{CO}$, and $9 \% \mathrm{CO}_{2}$. Another study by Papagiannakis et al. reported syngas component results of $19 \% \mathrm{H}_{2}, 29 \% \mathrm{CO}$, and $8 \% \mathrm{CO}_{2}$, by using natural gas as fuel instead of gasoline 91 [42].

\section{Materials and Methods}

\subsection{Experimental Setup}

The plasma system developed and tested in this experimental work was a part of a fuel reformer system used for a spark ignition (SI) engine test system. The SI engine test system is described in detail in previous works [36-39] and shown in Figure 2. Fuel reformation occurs in a controlled mixture of air, gasoline vapor, and steam at atmospheric pressure. The interaction between the constituents of the fuel mixture is initiated by energy of the plasma arc inside the discharge chamber. Then, the fuel reforming proceeds to completion when the components exit the discharge tubular reactor.

The plasma source of the fuel reformer consisted of an arc discharge chamber and a downstream quartz-lined reactor with a water-cooled vapor condenser. The plasma discharge chamber containing the tubular water-cooled anode was made of low-carbon steel. The swirling ring was mounted on the top of the anode case in the reactant gas inlet port plane. The air-steam-fuel mixture entered the chamber via the inlet port in the discharge chamber sidewall, and then, through the trenches of the swirling ring to create a vortex inside the anode channel. The cathode of the plasma system was a water-cooled copper tubular holder containing a small cylindrical tip made of an electron-emitting material. Figure $3 a$ shows the basic design of the plasma discharge chamber, and Figure $3 b$ shows a picture of the assembled chamber with the water-cooled cathode on top and water-cooled anode underneath. The cooling water inlets and outlets of the anode and cathode are seen in the picture. 


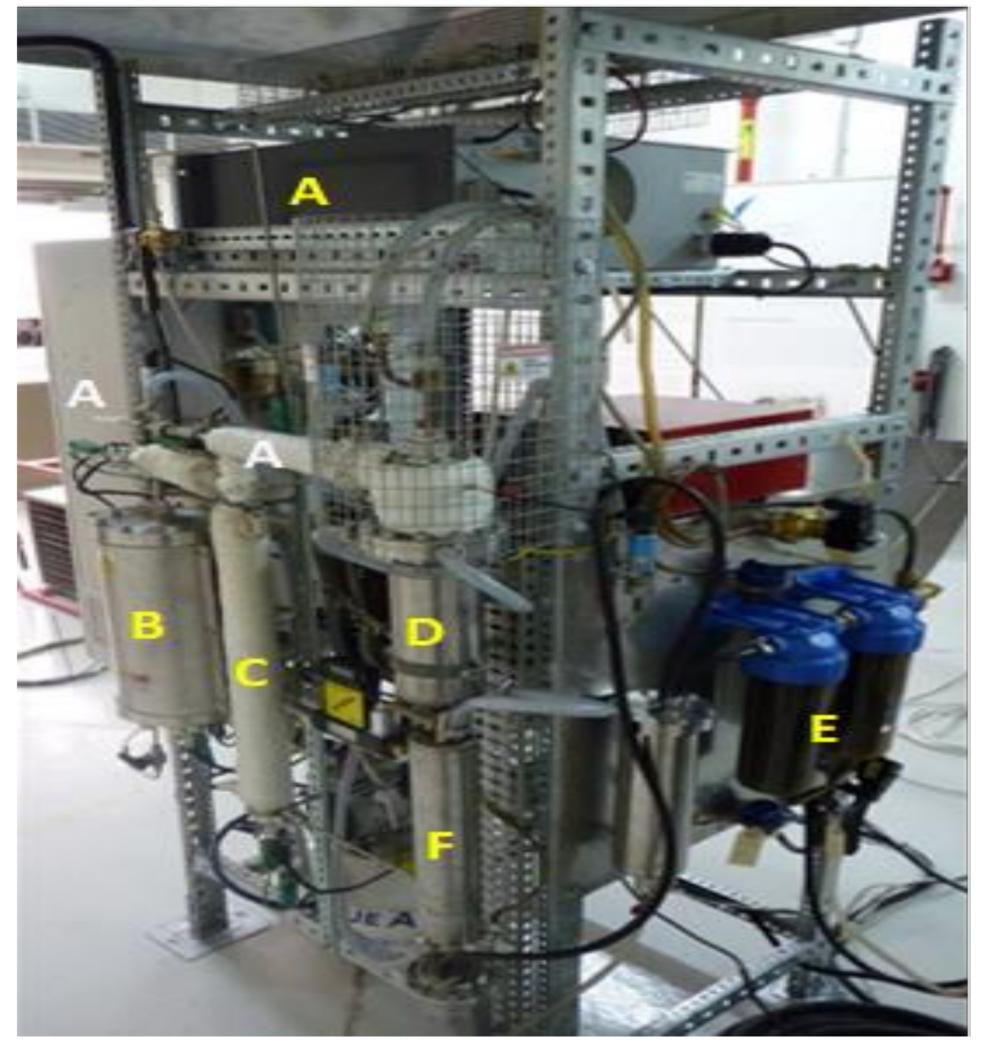

Figure 2. View of the test bench showing the following components: (A) power supply; (B) steam generator; (C) air heater; (D) reactor; (E) gas filters; (F) cooler.

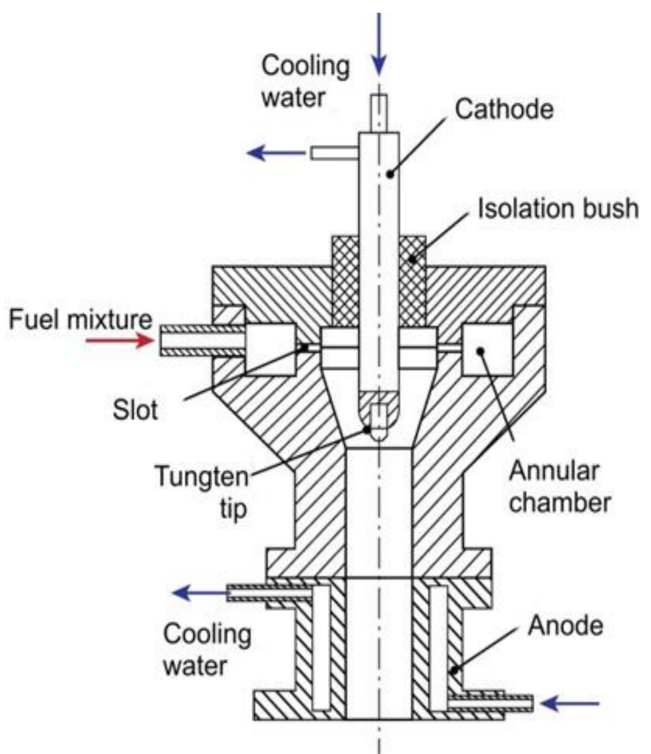

(a)

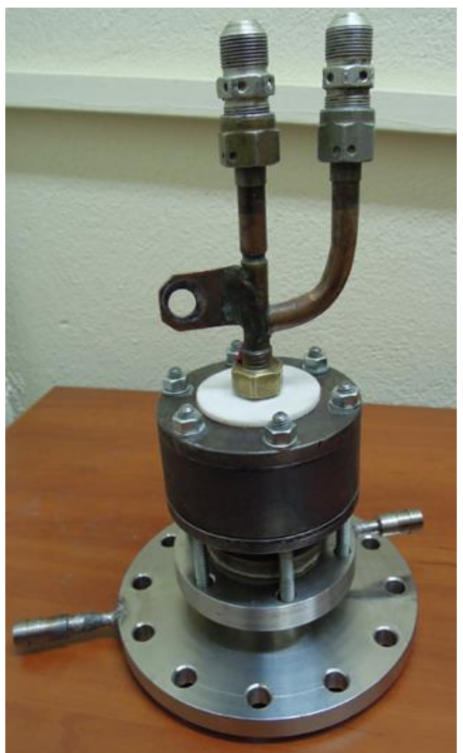

(b)

Figure 3. The plasma discharge chamber: (a) Discharge unit of the plasma converter; (b) assembled chamber with the cathode on top with the cooling water ports. The fuel mixture inlet is on the backside of the chamber.

The swirling ring is shown in Figure 4. Figure 5 shows a picture of the quartz-lined post-discharge reactor with thermal insulation, which was made of mineral wool, with water-cooled shell and flange made of stainless steel. 


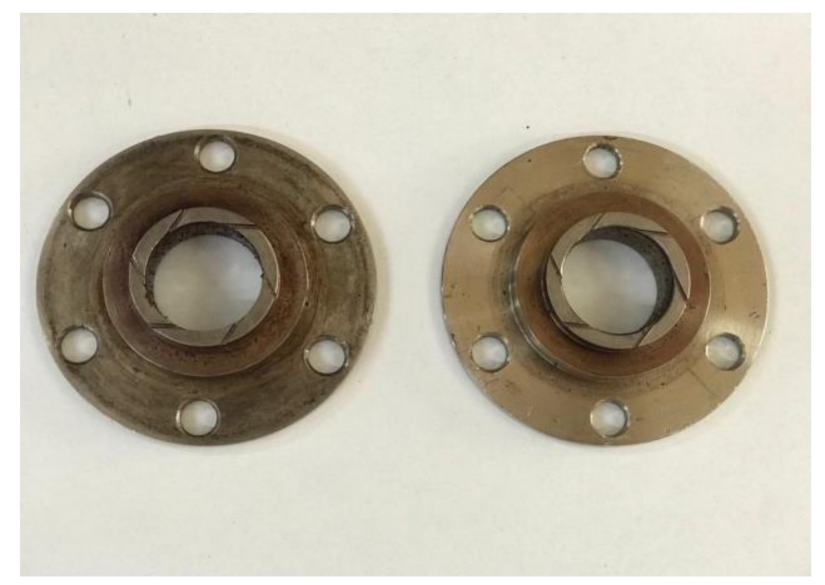

Figure 4. The swirling rings of the discharge chamber.

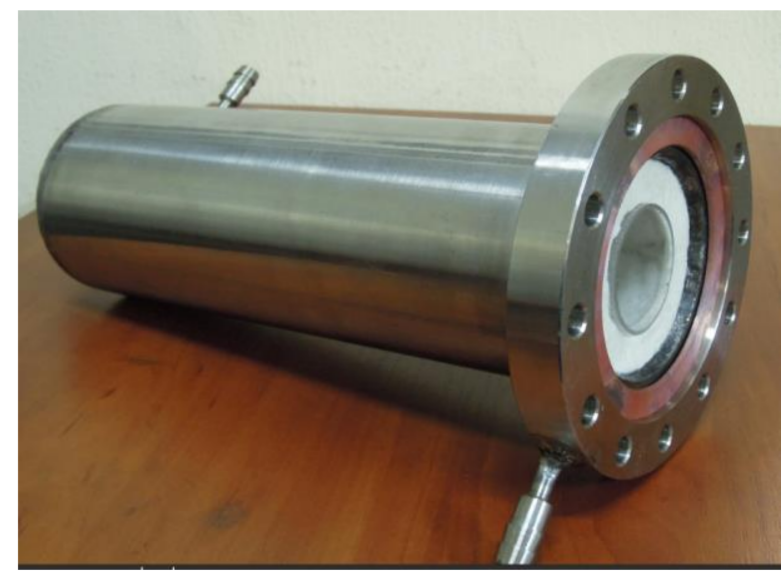

Figure 5. Quartz-lined post-discharge reactor with water-cooled shell and flange.

The high-voltage low-current DC power supply Technix SR10-N5000 was used to generate a plasma arc in the discharge chamber. The maximum output voltage of the power supply was $10 \mathrm{kV} \mathrm{DC}$, and the current varied from 0 to $500 \mathrm{~mA}$. The set of ballast resistors with $5200 \mathrm{Ohm}$ total resistance was connected in series in the power supply circuit to generate falling current-voltage characteristics after the discharge started, and thus, increase the plasma arc stability.

The mass flow of gasoline was controlled by an Ismatec ${ }^{\circledR}$ REGLO-CPF digital metering pump with accuracy: $\pm 1 \%$ at a flow rate range of $3-10 \mathrm{~g} / \mathrm{min}$. Gasoline RON 91 produced in Saudi Arabia was used as the fuel to be reformed in the experimental work. The air flow was set by an Omega 5400 mass flow controller. The steam was produced by an electric boiler, and then, steam was overheated when flowing through the steam heater. The steam flow rate was controlled by the pressure inside the steam generator and by the superheater temperature when passing via the orifice with the known constant diameter.

The syngas composition was measured continuously during the fuel reforming process by means of two Gascard NG infrared gas sensors (for separate $\mathrm{CO}$ and $\mathrm{CO}_{2}$ content analysis) and one INCOVT DV-32 electrolyte probe for hydrogen yield monitoring. Gascard NG sensors were used to measure $\mathrm{CO}$ and $\mathrm{CO}_{2}$ concentrations in the range of $0-30 \mathrm{vol} . \%$, with $\pm 2 \%$ accuracy. An INCOVT DV-32 probe was used to measure $\mathrm{H}_{2}$ concentrations in the range of $0-40$ vol. $\%$, with $\pm 2.5 \%$ accuracy.

Customized PC user interface software was designed to set, control, monitor, and log input and output parameters of the whole engine test system, including the arc voltage and temperature of the plasma fuel reformer in real-time mode. 


\subsection{Experimental Procedure}

In the experimental work, the hydrogen content in the reformate syngas was the main indicator of successful modification of the plasma system. The hydrogen content was measured during each modification of the plasma system configuration. Additionally, the voltage and power output were evaluated during these modifications.

Four anodes with various dimensions and cross sections were made, and then, used as modifications. All anodes were made of low-carbon steel, type AISI 1020. Differences in dimensions consisted of variations in the gas channel diameter. Differences in cross sections consisted of stepped or straight pattern variations of the gas channel. These variations are shown in Figures 6 and 7. The anodes were replaced in sequence within the discharge chamber to compare the resulting plasma system performances.

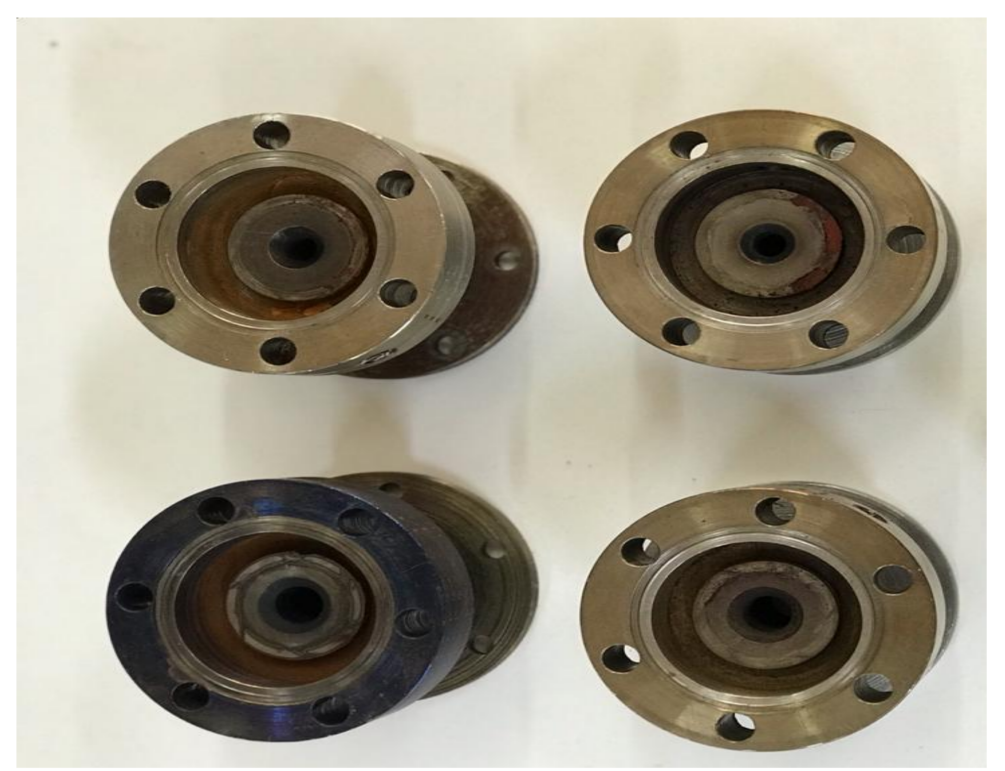

Figure 6. Four anodes with various dimensions and cross sections.
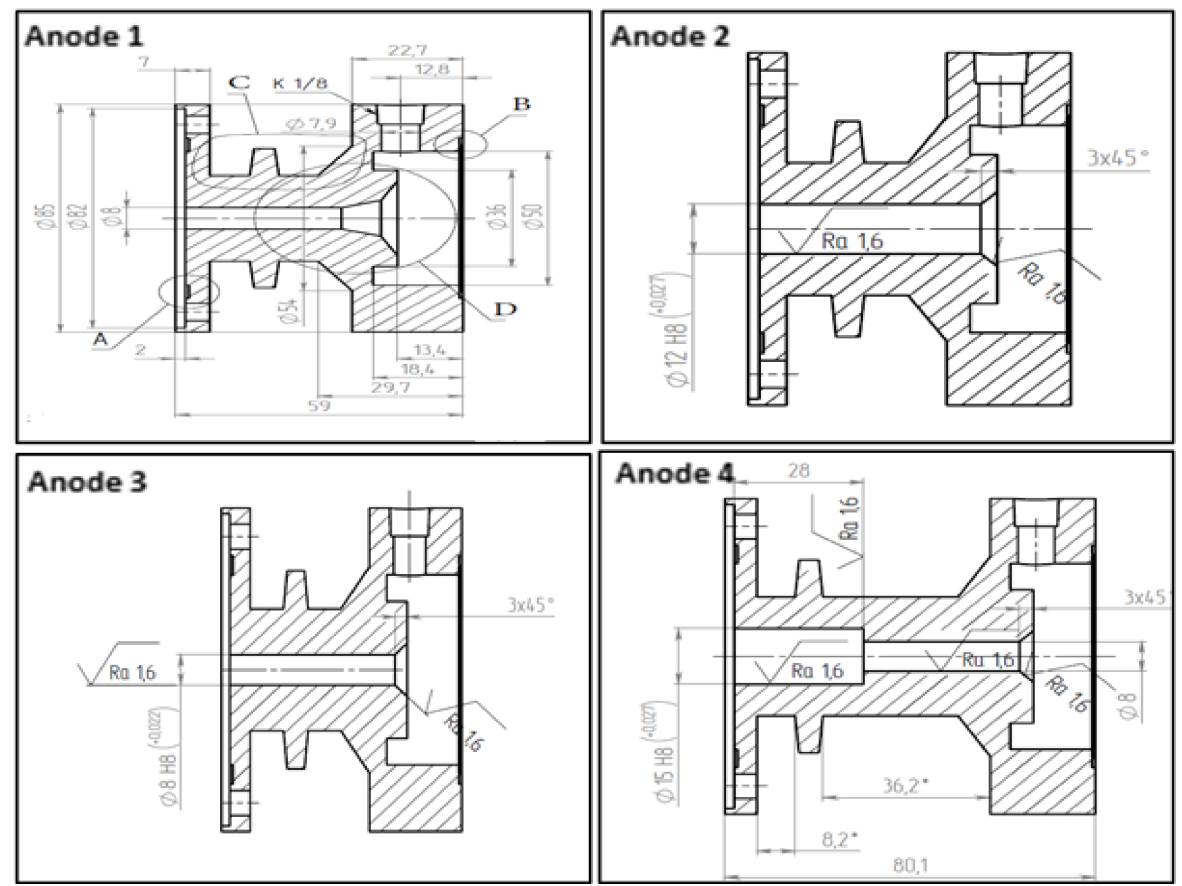

Figure 7. Four different designs of the anode from side view. 
Two copper cathodes with different emitting materials of the insert tip were prepared as modifications. The first emitting tip was made of hafnium metal of $99.8 \%$ purity. The second tip was made of lanthanated tungsten alloy, as shown in Figure 8. The lanthanated tungsten alloy used was EWLa-2, consisting of 1.6-2\% lanthanum oxide added to tungsten metal of $99.9 \%$ purity. The cathodes were compared in the fuel reforming process in terms of erosion resistance.

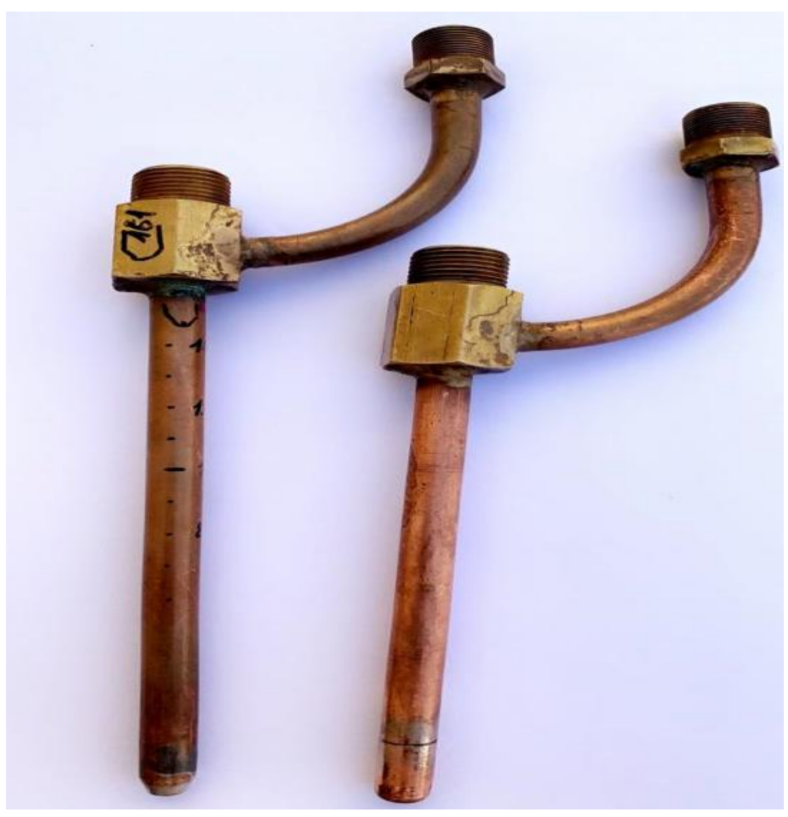

Figure 8. Two copper cathodes with different emitting materials.

Two swirling rings with trenches of different depth to width ratios were used as modifications of the gas stream flowing through the plasma discharge chamber. Ring 1 had $1 \times 1 \mathrm{~mm}$ trenches, and Ring 2 had $0.5 \times 1 \mathrm{~mm}$ trenches in terms of depth-width dimensions, as depicted in Figure 4. The plasma arc was initiated under direct current $500 \mathrm{~mA}$ and starting voltage $10 \mathrm{kV}$. The steady-state voltage of the discharge arc was, then, established at a certain range. The voltage range depended on the modifications of the plasma system used in each individual experiment series. Then, the plasma arc was maintained in the air-steam atmosphere until the temperature in the reactor outlet reached 450-500 ${ }^{\circ} \mathrm{C}$. After stabilization of the reactor temperature, gasoline was supplied to start the fuel reforming process. The air/fuel mass ratio (AFR) was set as 6 , and kept constant during the plasma performance test series. Gasoline was supplied to the fuel reformer with mass flow rates of $4 \mathrm{~g} / \mathrm{min}, 4.5 \mathrm{~g} / \mathrm{min}$, and $5 \mathrm{~g} / \mathrm{min}$. The air mass flow was set at $24 \mathrm{~g} / \mathrm{min}$, $27 \mathrm{~g} / \mathrm{min}$, and $30 \mathrm{~g} / \mathrm{min}$, as shown in Table 1 . The steam flow was set constant at $3.2 \mathrm{~g} / \mathrm{min}$ by maintaining the boiler pressure at $0.3 \mathrm{MPa}$. Concentrations of syngas components were monitored and recorded 5 min after the attainment of a steady state. At the steady-state level of syngas production, the temperature of the reactor was observed to stabilize at $700{ }^{\circ} \mathrm{C}$ and $850^{\circ} \mathrm{C}$ at the airflows of 24 and $30 \mathrm{~g} / \mathrm{min}$, respectively. 
Table 1. Fuel reformer system experiments.

\begin{tabular}{|c|c|c|c|c|c|}
\hline Experiment & Anode & Gas Ring (Ring 1) and (Ring 2) & Air Flow (g/min) & Fuel Flow (g/min) & AFR \\
\hline 1 & 1 & $\begin{array}{l}1 \\
2\end{array}$ & \multirow{4}{*}{$\begin{array}{l}24 \\
27 \\
30\end{array}$} & \multirow{4}{*}{$\begin{array}{c}4 \\
4.5 \\
5\end{array}$} & \multirow{4}{*}{6} \\
\hline 2 & 2 & $\begin{array}{l}1 \\
2\end{array}$ & & & \\
\hline 3 & 3 & $\begin{array}{l}1 \\
2\end{array}$ & & & \\
\hline 4 & 4 & $\begin{array}{l}1 \\
2\end{array}$ & & & \\
\hline
\end{tabular}

\section{Results and Discussion}

\subsection{Cathode Tip Erosion under Fuel Reforming Conditions}

Two comparative test series were performed using the hafnium metal cathode tip and the EWLa-2 alloy tip. The single test series consisted of three sequential fuel reforming runs at air/fuel rates of $30 / 5,27 / 4.5$, and $24 / 4 \mathrm{~g} / \mathrm{min}$, respectively, with a duration $15 \mathrm{~min}$ each. The steady-state discharge voltage was established within a range of 3.6-3.7 kV at $500 \mathrm{~mA}$ DC for both types of cathode tip during the tests.

It is well known that hafnium metal can react with oxygen or air to form hafnium dioxide. A hafnium metal/hafnium oxide $\left(\mathrm{Hf} / \mathrm{HfO}_{2}\right)$ system exhibits low erosion rates in an oxidative atmosphere [40]. Therefore, hafnium metal was expected to be an adequate material for the cathode tip under partial oxidation conditions of fuel reformation. In addition, hafnium has a low work function $(3.53 \mathrm{eV})$, high melting point, and acceptable electric and thermal conductivities.

The cathode was dismounted, and the cathode tip was inspected visually after each test series. The hafnium metal tip was found to be heavily eroded, as an erosion cavity, approximately $2 \mathrm{~mm}$ deep, was formed on the tip surface.

In contrast, the lanthanated tungsten EWLa-2 alloy only had good stability in a reductive atmosphere. In an oxidative atmosphere, tungsten reacts with oxygen to produce tungsten oxide, $\mathrm{WO}_{3}$, which is highly volatile at temperatures above $800{ }^{\circ} \mathrm{C}$. The lanthanated EWLa-2 alloy had favorable low work function (ca. $3 \mathrm{eV}$ ) as compared with the pure tungsten $(4.5 \mathrm{eV})$ due to the presence of lanthanum oxide. Lanthanum oxide migrates from inside the tungsten alloy to the heat at the cathode tip surface. Then, it is emitted at the tip to improve arc initiation and stability.

The EWLa-2 alloy tip exhibited no visible signs of metal erosion. This effect indicates that the atmosphere within the cathode region had a reductive character during the reforming process. Therefore, the cathode tip made of the lanthanated tungsten alloy was much more preferable than one made of hafnium metal. In this respect, further experiments were performed using the EWLa-2 alloy tip.

\subsection{Anode Design and Fuel Reforming Performance}

Four experimental series were conducted for different dimensions of anode with two swirl ring conditions, Ring 1 and Ring 2 design. The first experiment was performed with the dimensions of Anode 1 as illustrated in Figure 7, i.e., with a smooth funnel shape. The experimental results of Anode 1 with Rings 1 and 2 can be seen in Figure 9A,B. Initially, the system was in a steady state for the first few minutes when the mixture of fuel and air began to form in the reactor. The steady-state discharge voltage was established at approximately $4 \mathrm{kV}$ and $500 \mathrm{~mA}$ DC during the first and second experiments with the anode. The production of syngas started from the first $15 \mathrm{~min}$, while the experiment was conducted at air/fuel rates of $24 / 4 \mathrm{~g} / \mathrm{min}$, respectively, at a constant air/fuel mass ratio of 6. For the second and third $15 \mathrm{~min}$, the air flow rates were increased to 27 and $30 \mathrm{~g} / \mathrm{min}$, respectively. The highest percentage of syngas was $\mathrm{H}_{2}$ for both experiments as compared with $\mathrm{CO}$ and $\mathrm{CO}_{2}$. With Ring 2, the hydrogen reached $21 \%$, while it reached $24 \%$ with Ring 1. This may be attributed to the differences in the swirl ring dimensions, i.e., $0.5 \times 1 \mathrm{~mm}$ 
(depth $\times$ width) for the Ring 1 design. The percentage of $\mathrm{CO}_{2}$ represented the lowest level of syngas component, i.e., $6 \%$, almost completely from the start to the end of all experiments with Ring 2. Notably, the voltage discharge increased by the end of the experiment, due to an increase in pressure during closing of the system.
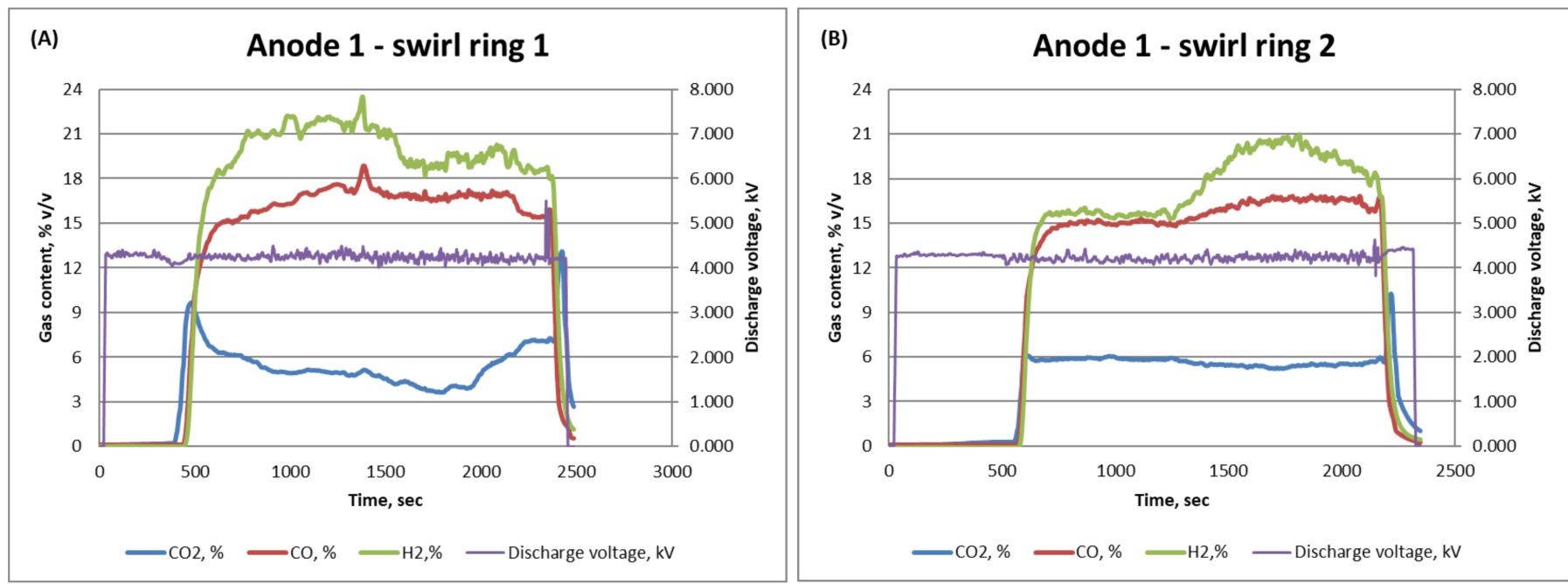

Figure 9. Comparison between Ring 1 (A) and Ring 2 (B) with Anode 1.

The second experiment was performed with the second anode (Anode 2). The experimental results of Anode 2 with Rings 1 and 2 are shown in Figure 10A,B. It is clear from the figures that the largest percentage of syngas was $\mathrm{CO}$ in both experiments: around $15 \%$ and $14 \%$ in Rings 1 and 2, respectively. The percentage of hydrogen was at the highest level in the first $15 \mathrm{~min}$ in both ring designs, with air and fuel flow rates of 24 and $4 \mathrm{~g} / \mathrm{min}$, respectively. After that, it decreased gradually to around $12 \%$. This situation may have occurred because of the differences in the air and fuel flow rates. The percentage of $\mathrm{CO}_{2}$ was the least abundant syngas component, at around $6 \%$ for all the experiments at various air-fuel flow rates.
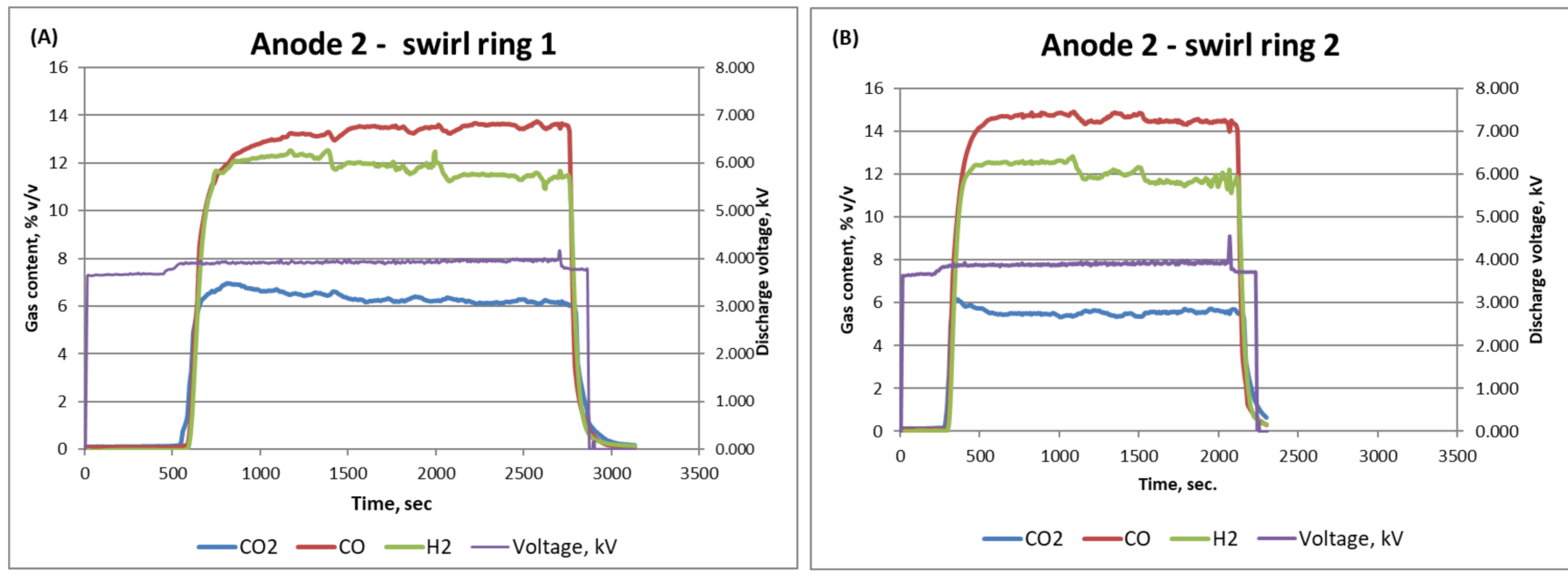

Figure 10. Comparison between Ring 1 (A) and Ring 2 (B) with Anode 2.

The third experiment was performed with the third anode (Anode 3). The experimental results of Anode 3 with Rings 1 and 2 are shown in Figure 11A,B. A stable level of discharge voltage was established at approximately $3.7 \mathrm{kV}$ for the third and fourth anode experiments. The maximum proportion of $\mathrm{CO}$ was almost $13 \%$ in both trials for syngas; however, with 
the Ring 1 design, the reaction began earlier than the previous design. The proportion of hydrogen was over $10 \%$ and started to decrease slightly, to under $10 \%$ in both runs, although with Ring 1, a greater decrease occurred with air/fuel flow rate of 30/5 g/min, respectively. The edged funnel shape of the anode gas inlet resulted in a lower yield of hydrogen $(9 \% v / v$ of gas content).
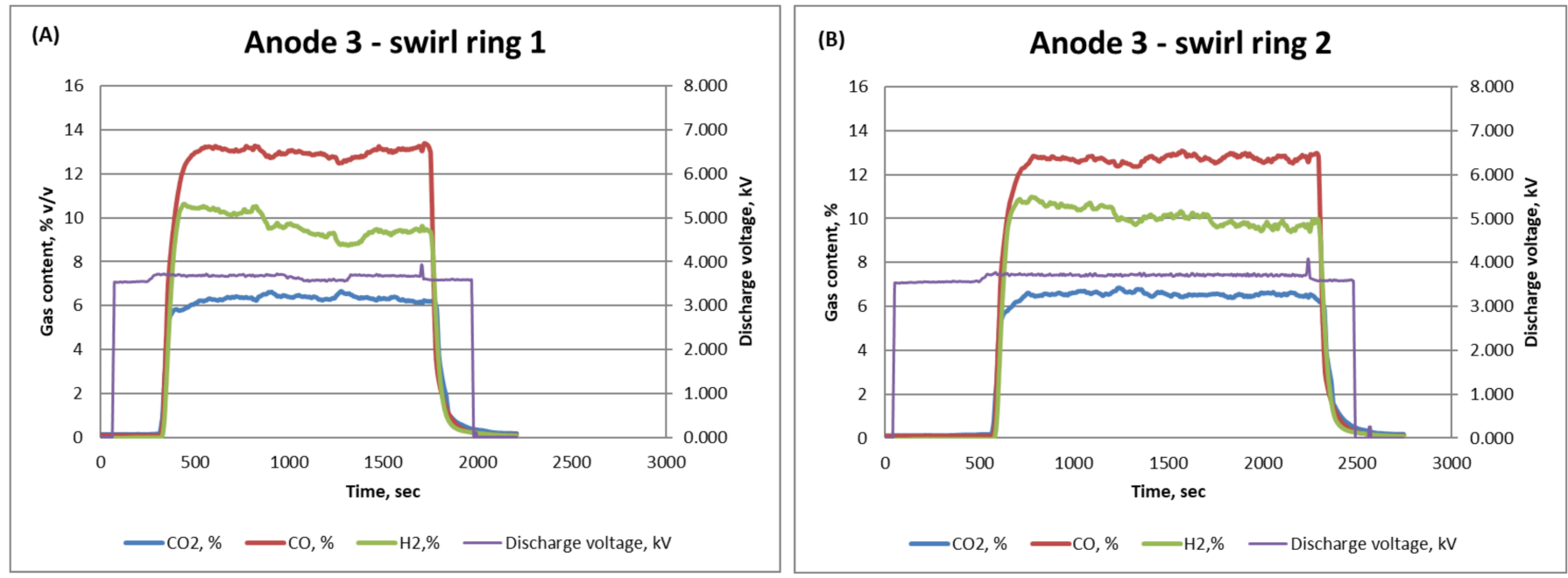

Figure 11. Comparison between Rings 1 (A) and 2 (B) with Anode 3.

The fourth run was performed with the anode dimensions shown in Figure 7. The experimental results of Anode 4 with Rings 1 and 2 are shown in Figure 12A,B, respectively. The maximum amount of $\mathrm{CO}$ was almost $14 \%$ in both trials of syngas. However, with Ring 1, the reaction showed a delay in the startup in contrast to the old design. In addition, with the new design, $\mathrm{CO}$ increased gradually, while Ring 2 maintained a steady-state condition. In the Ring 2 design, the proportion of hydrogen was slightly over $10 \%$ at air/fuel flow rates of $24 / 4$ and $27 / 4.5 \mathrm{~g} / \mathrm{min}$, respectively. In Ring 1 , the proportion of hydrogen was almost at the same level, constituting $10 \%$ of the total syngas. The maximum syngas contents in each experiment are shown in Table 2.
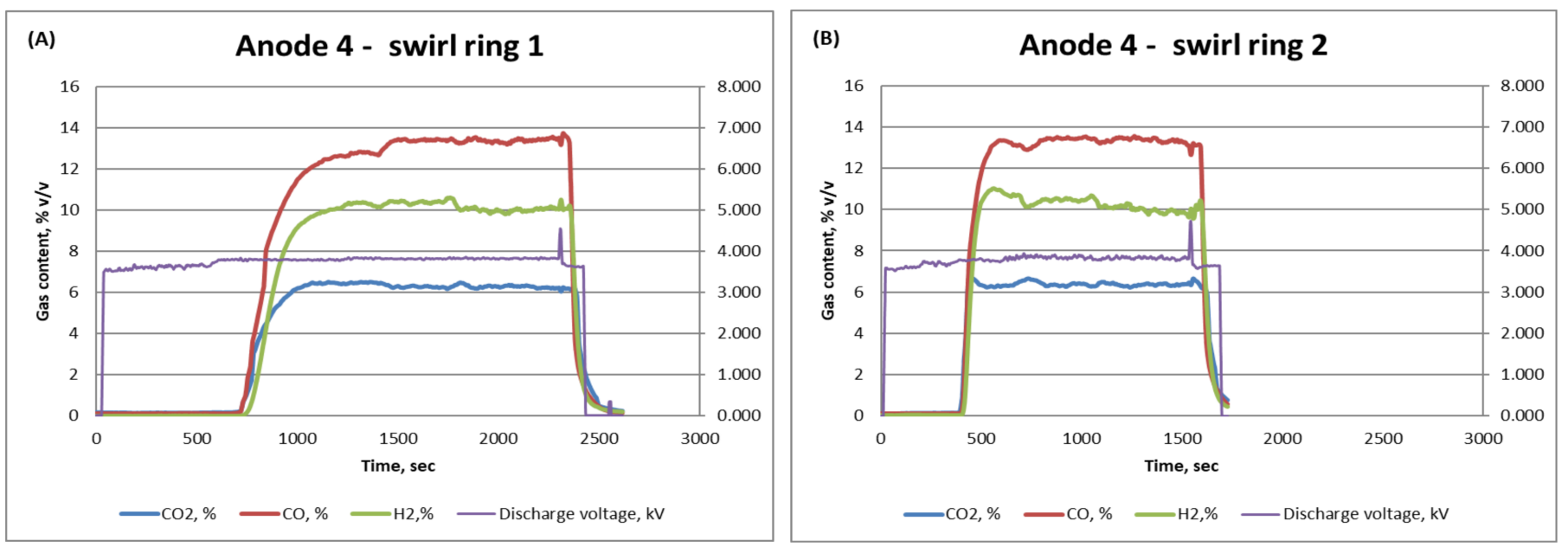

Figure 12. Comparison between Rings 1 (A) and 2 (B) with Anode 4. 
Table 2. Maximum syngas content in each experiment.

\begin{tabular}{cccc}
\hline Design & $\mathbf{H}_{\mathbf{2}} \mathbf{\%}$ & $\mathbf{C O} \%$ & $\mathbf{C O}_{\mathbf{2}} \mathbf{\%}$ \\
\hline Anode 1-Ring 1 & 24 & 19 & 9 \\
Anode 1-Ring 2 & 21 & 16 & 6 \\
Anode 2-Ring 1 & 12 & 14 & 7 \\
Anode 2-Ring 2 & 12 & 15 & 5.5 \\
Anode 3-Ring 1 & 15 & 13 & 7 \\
Anode 3-Ring 2 & 11 & 13 & 7 \\
Anode 4-Ring 1 & 10.5 & 14 & 6 \\
Anode 4-Ring 2 & 11 & 13 & 6 \\
\hline
\end{tabular}

From Figures 9-12, it can be seen that, regardless of the reformer configuration, hydrogen concentration decreased with increasing air mass flow from 24 to $30 \mathrm{~g} / \mathrm{min}$ at fixed conditions of AFR and input power. This behavior may be attributed to the reduction in specific input energy (SIE) associated with increasing the air and fuel mass flow at a constant input power [43]. Another possible reason for the decrease in hydrogen concentration with increasing mass flow of air is the reduction in the residence time of the reactants within the reformer.

\section{Conclusions}

In this study, an experimental investigation of a plasma fuel reformer system was performed to optimize the production of hydrogen-rich syngas. Four types of anode designs, two types of swirl rings, and different inlet air/fuel flow rates were tested, while a 91 RON gasoline fuel was used in all the reformation processes. Resistance of two cathode materials to erosion was also investigated. From all the experiments, hydrogen was found as the highest proportion of the produced syngas. With regards to the configuration of the plasma fuel reformer system, it was found that the highest production of syngas yield with enhanced hydrogen composition was obtained from the configuration of the smooth funnel shape (Anode 1) and the swirl ring that had a width/depth ratio of 1:1, producing a hydrogen proportion of $24 \%$. During the experiments, lanthanated tungsten plasma torch displayed greater resistance to erosion than plasma torch made of hafnium metal. It is expected that the use of this optimized plasma reformer system in IC engines will reduce the total energy consumption required for on-board hydrogen-rich syngas production, towards a more beneficial operation of fuel consumption and NOx emission reduction.

Author Contributions: Conceptualization, A.A.A. (Ahmed A. Alharbi), N.B.A., A.M.A.; methodology, A.J.A. and A.A.A. (Ahmad A. Almaleki); formal analysis: M.H.A., M.S.A. and A.A.A. (Abdullah A. Almayeef); resources, A.A.A. (Ahmed A. Alharbi) and A.J.A.; writing-original draft, A.A.A. (Ahmed A. Alharbi), N.B.A. and A.M.A.; writing-review and editing, A.J.A., M.H.A. and M.S.A. All authors have read and agreed to the published version of the manuscript.

Funding: This research received no external funding.

Institutional Review Board Statement: Not applicable.

Informed Consent Statement: Not applicable.

Data Availability Statement: Data is contained within the article.

Acknowledgments: The authors acknowledge the financial support from the Water and Energy Research Institute, King Abdulaziz City of Science and Technology, project no. 33-906, "Development, construction and delivery of on-board plasma based fuel reformer for higher IC engine efficiency". In addition, we acknowledge Bader A. Alfaraj for his assistance in reviewing the paper.

Conflicts of Interest: The authors declare no conflict of interest. 


$\begin{array}{ll}\text { Abbreviations } \\ \text { APU } & \text { auxiliary power unit } \\ \text { POX } & \text { partial oxidation } \\ \text { SI } & \text { spark ignition } \\ \text { SR } & \text { steam reforming } \\ \text { NOx } & \text { nitrogen oxides } \\ \text { ATR } & \text { autothermal reforming } \\ \mathrm{CnHm} & \text { hydrocarbons } \\ \mathrm{CO} & \text { carbon monoxide } \\ \mathrm{CO} & \text { carbon dioxide } \\ \mathrm{AFR} & \text { air/fuel mass ratio }\end{array}$

\section{References}

1. Conte, E.; Boulouchos, K. Influence of Hydrogen-Rich-Gas Addition on Combustion, Pollutant Formation and Efficiency of an IC-SI Engine; SAE Technical Paper Series; SAE International: Warrendale, PE, USA, 2004. [CrossRef]

2. Tully, E.J.; Heywood, J.B. Lean-Burn Characteristics of a Gasoline Engine Enriched with Hydrogen Plasmatron Fuel Reformer; SAE Technical Paper Series; SAE International: Warrendale, PE, USA, 2003. [CrossRef]

3. Quader, A.A.; Kirwan, J.E.; Grieve, M.J. Engine Performance and Emissions near the Dilute Limit with Hydrogen Enrichment Using an On-Board Reforming Strategy; SAE Technical Paper Series; SAE International: Warrendale, PE, USA, 2003. [CrossRef]

4. Sobyanin, V.; Sadykov, V.; Kirillov, V.; Kuzmin, V.; Kuzin, N.; Vostrikov, Z.; Smirnov, E.; Sorokin, A.; Brizitskiy, O.; Terentyev, V.; et al. Syngas as a fuel for IC and diesel engines: Efficiency and harmful emissions cut off. In Proceedings of the International Hydrogen Energy Congress and Exhibition, Istanbul, Turkey, 13-15 July 2005.

5. Kirwan, J.; Quader, A.; Grieve, M. Advanced Engine Management Using On-Board Gasoline Partial Oxidation Reforming for Meeting Super-ULEV (SULEV) Emissions Standards; SAE Technical Paper 1999-01-2927; SAE International: Warrendale, PE, USA, 1999. [CrossRef]

6. $\quad$ Lindstrom, B.; Karlsson, J.; Ekdunge, P.; De Verdier, L.; Häggendal, B.; Dawody, J.; Nilsson, M.; Pettersson, L. Diesel fuel reformer for automotive fuel cell applications. Int. J. Hydrog. Energy 2009, 34, 3367-3381. [CrossRef]

7. Bromberg, L.; Cohn, D.R.; Rabinovich, A.; Heywood, J. Emissions reductions using hydrogen from plasmatron fuel converters. Int. J. Hydrog. Energy 2001, 26, 1115-1121. [CrossRef]

8. Samsun, R.C.; Prawitz, M.; Tschauder, A.; Pasel, J.; Pfeifer, P.; Peters, R.; Stolten, D. An integrated diesel fuel processing system with thermal start-up for fuel cells. Appl. Energy 2018, 226, 145-159. [CrossRef]

9. Kang, I.; Bae, J. Autothermal reforming study of diesel for fuel cell application. J. Power Sources 2006, 159, 1283-1290. [CrossRef]

10. Bensaid, S.; Specchia, S.; Federici, F.; Saracco, G.; Specchia, V. MCFC-based marine APU: Comparison between conventional ATR and cracking coupled with SR integrated inside the stack pressurized vessel. Int. J. Hydrog. Energy 2009, 34, 2026-2042. [CrossRef]

11. Bromberg, L.; Cohn, D.R.; Rabinovich, A.; Alexeev, N. Hydrogen Manufacturing Using Low Current, Non-Thermal Plasma Boosted Fuel Converters. In Proceedings of the Symposium on Energy for the 21st Century: Hydrogen Energy; Report No. PSFC/RR-01-1; The Fuel Chemistry Division of the American Chemical Society: San Diego, CA, USA, 2001.

12. Yoon, S.; Kang, I.; Bae, J. Effects of ethylene on carbon formation in diesel autothermal reforming. Int. J. Hydrog. Energy 2008, 33, 4780-4788. [CrossRef]

13. Bromberg, L.; Cohn, D.R.; Rabinovich, A.; Alexeev, N.; Samokhin, A.; Hadidi, K.; Palaia, J.; Margarit-Bel, N. Onboard Plasmatron Hydrogen Production for Improved Vehicles; PSFC JA-06-3; MIT Plasma Science and Fusion Center: Cambridge, MA, USA, 2006.

14. Kim, T.-S.; Song, S.; Chun, K.-M.; Lee, S.H. An experimental study of syn-gas production via microwave plasma reforming of methane, iso-octane and gasoline. Energy 2010, 35, 2734-2743. [CrossRef]

15. Darmon, A.; Rollier, J.D.; Duval, E.; Gonzalez-Aguilar, J.; Metkemeijer, R.; Fulcheri, L. Plasma assisted fuel reforming for on-board hydrogen rich gas production. In Proceedings of the 16th World Hydrogen Energy Conference, Lyon, France, $13-16$ June 2006.

16. Rollier, J.-D.; Gonzalez-Aguilar, J.; Petitpas, G.; Darmon, A.; Fulcheri, L.; Metkemeijer, R. Experimental Study on Gasoline Reforming Assisted by Nonthermal Arc Discharge. Energy Fuels 2007, 22, 556-560. [CrossRef]

17. Piavis, W.; Turn, S.; Ali Mousavi, S.M. Non-thermal gliding-arc plasma reforming of dodecane and hydroprocessed renewable diesel. Int. J. Hydrog. Energy 2015, 40, 13295-13305. [CrossRef]

18. Hartvigsen, J.; Hartvigsen, J.; Elangovan, S.; Hollist, M.; Czernichowski, P.; Frost, L. Non-Thermal Plasma Reformation of Liquid Fuels. ECS Trans. 2011, 35, 2825-2833. [CrossRef]

19. Paulmier, T.; Fulcheri, L. Use of non-thermal plasma for hydrocarbon reforming. Chem. Eng. J. 2005, 106, 59-71. [CrossRef]

20. Sobacchi, M.G.; Saveliev, A.V.; Fridman, A.A.; Kennedy, L.A.; Ahmed, S.; Krause, T. Experimental assessment of a combined plasma/catalytic system for hydrogen production via partial oxidation of hydrocarbon fuels. Int. J. Hydrog. Energy 2002, 27, 635-642. [CrossRef]

21. Czylkowski, D.; Hrycak, B.; Miotk, R.; Jasiński, M.; Mizeraczyk, J.; Dors, M. Microwave plasma for hydrogen production from liquids. Nukleonika 2016, 61, 185-190. [CrossRef] 
22. Malik, M.A.; Hughes, D.; Malik, A.; Xiao, S.; Schoenbach, K.H. Study of the Production of Hydrogen and Light Hydrocarbons by Spark Discharges in Diesel, Kerosene, Gasoline, and Methane. Plasma Chem. Plasma Process. 2012, 33, 271-279. [CrossRef]

23. Gallagher, M.J.; Geiger, R.; Polevich, A.; Rabinovich, A.; Gutsol, A.; Fridman, A. On-board plasma-assisted conversion of heavy hydrocarbons into synthesis gas. Fuel 2010, 89, 1187-1192. [CrossRef]

24. Mechtly, E. Properties of Materials. In Reference Data for Engineers: Radio, Electronics, Computer, and Communications; Van Valkenburg, M.E., Middleton, W.M., Eds.; Elsevier: Amsterdam, The Netherlands, 2002. [CrossRef]

25. Lee, D.H.; Kim, K.-T.; Song, Y.-H.; Kang, W.S.; Jo, S. Mapping Plasma Chemistry in Hydrocarbon Fuel Processing Processes Plasma Chem. Plasma Process. 2013, 33, 249-269. [CrossRef]

26. Gutsol, A. Warm discharges for fuel conversion. In Handbook of Combustion; New technologies; Lackner, M., Winter, F., Agarwal, A.K., Eds.; Wiley-VCH: Weinheim, Germany, 2010; Volume 5, pp. 323-353.

27. Benilov, M.; Naidis, G. Modeling of hydrogen-rich gas production by plasma reforming of hydrocarbon fuels. Int. J. Hydrog. Energy 2006, 31, 769-774. [CrossRef]

28. Benilov, M.; Naidis, G. Modelling of low-current discharges in atmospheric-pressure air taking account of non-equilibrium effects. J. Phys. D Appl. Phys. 2003, 36, 1834-1841. [CrossRef]

29. Lebouvier, A.; Delalondre, C.; Fresnet, F.; Boch, V.; Rohani, V.-J.; Cauneau, F.; Fulcheri, L. Three-Dimensional Unsteady MHD Modeling of a Low-Current High-Voltage Nontransferred DC Plasma Torch Operating with Air. IEEE Trans. Plasma Sci. 2011, 39, 1889-1899. [CrossRef]

30. Lee, D.H.; Kim, K.-T.; Cha, M.S.; Song, Y.-H. Plasma-controlled chemistry in plasma reforming of methane. Int. J. Hydrog. Energy 2010, 35, 10967-10976. [CrossRef]

31. Dinh, D.K.; Lee, D.H.; Song, Y.-H.; Jo, S.; Kim, K.-T. Arc length control for efficiency enhancement of energy usage in plasma dry reforming process. J. CO2 Util. 2018, 28, 274-282. [CrossRef]

32. Lebouvier, A.; Delalondre, C.; Fresnet, F.; Cauneau, F.; Fulcheri, L. 3D MHD modelling of low current-high voltage dc plasma torch under restrike mode. J. Phys. D Appl. Phys. 2011, 45, 25204-25212. [CrossRef]

33. Cao, X.; Yu, D.; Xiao, M.; Miao, J.; Xiang, Y.; Yao, J. Design and Characteristics of a Laminar Plasma Torch for Materials Processing Plasma Chem. Plasma Process. 2015, 36, 693-710. [CrossRef]

34. Fulcheri, L.; Rollier, J.-D.; Gonzalez-Aguilar, J. Design and electrical charaterization of a low current-high voltage compact arc plasma torch. Plasma Sources Sci. Technol. 2006, 16, 183-192. [CrossRef]

35. Essiptchouk, A. Influence of inlet conditions on vortex characteristics. J. Eng. Phys. Thermophys. 2011, 84, 1126-1131. [CrossRef]

36. Alharbi, A.A.; Alenazey, F.S.; Migoun, A.N.; Dmitrenko, Y.M.; Zhdanok, S.A. Reducing Pollution Emissions by Adding Syngas Generated by a Plasma-Assisted Gasoline Converter in the Intake Manifold of a Gasoline Engine with Electronic Fuel Injection System. Heat Transf. Res. 2016, 47, 1073-1082. [CrossRef]

37. Alharbi, A.A.; Binjuwair, S.A.; Alshunaifi, I.A.; Alkhedhair, A.M.; Alabduly, A.J.; Almorat, M.S.; Albishi, M.S. NOx Emission Reduction Using Hydrous Ethanol-Gasoline Blend with Syngas in SI Engine. J. Environ. Prot. 2019, 10, 1278-1298. [CrossRef]

38. Alharbi, A.A.; Alenazey, F.S.; Binjuwair, S.A.; Alshunaifi, I.A.; Alkhedhair, A.M.; Alabduly, A.J.; Almorat, M.S.; Albishi, M.S. Effect of adding hydrogen-rich synthesis gas and ethanol on NOx emissions with gasoline at different air/fuel mixtures. J. Eng. Res. 2020, 8, 1-16. [CrossRef]

39. Alharbi, A.A.; Alabduly, A.J.; Alkhedhair, A.M.; Alqahtani, N.B.; Albishi, M.S. Effect of operation under lean conditions on NOx emissions and fuel consumption fueling an SI engine with hydrous ethanol-gasoline blends enhanced with synthesis gas. Energy 2022, 238, 121694

40. Ghorui, S.; Meher, K.C.; Kar, R.; Tiwari, N.; Sahasrabudhe, S.N. Unique erosion features of hafnium cathode in atmospheric pressure arcs of air, nitrogen and oxygen. J. Phys. D Appl. Phys. 2016, 49, 295201. [CrossRef]

41. Alenazey, F.S.; Al-Harbi, A.A.; Chernukho, A.P.; Dmitrenko, Y.M.; Migoun, A.N.; Zhdanok, S.A. Syngas Production from Propane- Butane Mixtures Using a High-Voltage Atmospheric Pressure Discharge Plasma. Heat Transf. Res. 2016, 47, 1057-1072. [CrossRef]

42. Papagiannakis, R.G.; Rakopoulos, C.D.; Hountalas, D.T.; Giakoumis, E.G. Study of the performance and exhaust emissions of a spark-ignited engine operating on syngas fuel. Int. J. Altern. Propuls. 2007, 1, 190-215. [CrossRef]

43. Alabduly, A.; Christensen, P.; Harvey, A. The characterization of a packed bed plasma reactor for ozone generation. Plasma Sources Sci. Technol. 2020, 29, 035002. 